\title{
Bir Şehir Hastanesinde İstenilen Psikiyatri Konsültasyonlarının Değerlendirilmesi: 2019 Yılı Verileri
}

\section{An Analysis On The Requested Psychiatric Consultations In A City Hospital: The Data Of The Year 2019}

iD Gülay Taşc1 ${ }^{1}$

${ }^{1}$ Elazığ Fethi Sekin Şehir Hastanesi, Ruh Sağlığı ve Hastalıkları Bölümü, Elazı̆̆

$\ddot{\mathbf{O z}}$

Amaç: Yapılan literatür taramasında, Elazığ ilinin verilerini bir yılı esas alarak ele alan bir konsültasyon-liyezon psikiyatrisi çalışması bulunmadığı görülmüştür. Bu çalışmanın amacı bir yıllık süre içerisinde istenen psikiyatri konsültasyonlarını geriye dönük olarak tarayarak, hastaların demografik verilerinin, fiziksel ve psikiyatrik tanılarının ve aldıkları tedavilerinin incelenmesidir.

Gereç ve Yöntem: Hastanemizde yatarak tedavi gören veya acil servise ayaktan başvuran, psikiyatri konsültasyonu istenen 18 yaş ve üstü hastaların verileri, hastane kayıt sistemi üzerinden incelenmiştir. Yaş, cinsiyet gibi sosyodemografik veriler, konsultasyon isteminde bulunan bölüm adı, bu bölümlerdeki ana yatı̧ tanısı ve konulan psikiyatrik tanılar yapılandırılmış bir forma kaydedilmiştir. Tanısal değerlendirme, DSM-5 tanı kriterlerine göre yapılmıştır. Araştırmada incelenen veriler için tanımlayıcı istatistiksel analizler yapılmıştır.

Bulgular: Toplamda 961 hastaya psikiyatri konsültasyon hizmeti verilmiştir. Hastaların 511'i (\%53.2) kadın, 450'si (\% 46.8) erkeklerden oluşuyordu. Kadınların yaş ortalaması 53.65 \pm 21.5 yıll, erkeklerin ise $57.59 \pm 21.38$ yıl idi. Bunlardan 23 (\%2.4) kişi acil servise ayaktan başvuran, 204 (\%21.2) kişi yoğun bakım ünitesinde (YBÜ), 280 (\%29.1) kişi cerrahi servislerde, 454 (\% 47.3$)$ kişi ise dahili servislerde yatarak tedavi gören hastalardı. Konsültasyon istemlerinin büyük kısmı; konsültasyon isteme gerekçesi göstermeksizin hastanın psikiyatrik yönden değerlendirilmesi (\%68), kaygı (\%7), uykusuzluk (\%5) ve operasyon öncesi psikiyatrik değerlendirme (\%5) nedeniyledir. Diyabet (DM), hipertansiyon (HT) gibi endokrinolojik hastalıklar ( $\mathrm{n}=228, \%$ 23.7), KOAH (kronik obstruktif akciğer hastalı̆̆ı), astım gibi göğüs hastalıkları ile ilgili hastalıklar ( $\mathrm{n}=165, \% 17.2)$ en sık eşlik eden fiziksel hastalıklardı. DSM-5 tanı kriterlerine göre konulan psikiyatrik tanılar ise; anksiyete bozuklukları 409 (\%42.6), depresif bozukluk 131 (\%13.6), uyum bozukluğu 70 (\%7.3) kiși ile en sık konulan tanılar idi. Hastaların \%68.5'i antidepresanlarla, \%4.7'si antipsikotiklerle tedavi edilmiş olup, \% \%19.8'ine ilaçsız izlem önerilmiştir. Öz kıyım girişiminde bulunan hastalar 123 (\% 12.8) kişi idi. Hastalardan 71 (\%57.73)'i kadın, 52 (\%42.27)'si erkekti. Hastaların yaş ortalaması $30.64 \pm 5.64$ idi. Depresif bozukluk ve anksiyete bozukluğu en sık konulan tanılardı.

Sonuç: Çalışmamızda en fazla konsültasyon istemi göğüs hastalıkları ve dahiliye kliniklerince yapılmıştır. En sık konsültasyon isteme nedeni ise bir gerekçe göstermeksizin hastanın psikiyatrik yönden değerlendirilmesi olarak bulunmuştur. Yapılan psikiyatrik değerlendirme sonrasında en sık konulan tanılar anksiyete ve depresif bozukluklar olmuştur. Bu çalışma Elazığ ili psikiyatri konsültasyonlarını inceleyen ilk çalışmadır. Bu çalışma ile diğer illerde yapılan çalıșmaların karşılaştırılması ve psikiyatrik yaklaşımlara yön vermesi amaçlanmaktadır.

Anahtar kelimeler: Psikiyatri, konsültasyon, fiziksel hastalık, yatan hasta.

Abstract

Objective: In the literature review, it was seen that there was no consultation-liaison psychiatry study that took the data of Elazığ province on the basis of one year. The aim of this study is to investigate the patients> demographic data, physical-psychiatric diagnosis and management by retrospectively looking at the psychiatry consultations requested within a one-year period.

Materials and Methods: The data of the inpatients at the age of 18 and above in our hospital or who applied to the emergency department as outpatients were examined from the hospital registration system. Sociodemographic data such as age, gender, the name of the department requesting consultation, diagnosis of the main hospitalization in these departments and the psychiatric diagnosis were recorded on a structred form. Diagnostic evaluations were made according to DSM- 5 criteria. Descriptive statistical analyzes were performed for the data examined in the study.

Results: Psychiatric consultation was requested for 961 patients in total. $511(53.2 \%)$ of the patients were female and $450(46.8 \%)$ of them were male. The mean age for females was $53.65 \pm 21.5$ years and $57.59 \pm 21.38$ for males. $23(2.4 \%)$ of the patients applied to the emergency department as outpatients. $204(21.2 \%)$ of the patients were treated in intensive care unit, $280(29.1 \%)$ in surgery ward and $454(47.3 \%)$ of them were treated in internal medicine wards as inpatient. The most frequent causes of psychiatric consultations were evaluation of the patients without indicating any reason for consultation referral $(\% 68)$, anxiety $(\% 7)$, insomnia $(\% 5)$ and pre-operative psychiatric evaluation $(\% 5)$. Endocrinological diseases such as diabetes $(\mathrm{DM})$, hypertension $(\mathrm{HT})(\mathrm{n}=228$, $23.7 \%$ ), diseases associated with chest diseases such as COPD (chronic obstructive pulmonary disease), asthma $(\mathrm{n}=165,17.2 \%)$ were the most common accompanying physical diseases. As for psychiatric diagnoses made according to DSM-5 diagnostic criteria; there were anxiety disorders in 409 (42.6\%), depressive disorder in 131 (13.6\%), adjustment disorder in 70 ( $7.3 \%)$ individuals were the most common diagnoses. Among all patients $68.5 \%$ were treated with antidepressants, $4.7 \%$ with antipsychotics, $19.8 \%$ of were offered to be followed up without drug treatment. 123 $(12.8 \%)$ individuals were found to have attempted to suicide. $71(57.73 \%)$ of the patients were female and $52(42.27 \%)$ of them were male. The mean age of the patients was $30.64 \pm 5.64$. The most common diagnoses were found to be depressive disorder and anxiety disorder.

Conclusion: In our study, the concultations most frequent received from are the chest diseases department and the internal medicine departments. The most frequent cause of requirement of the concultations is psychiatric examination without any spesific reason. Anxiety and depressive disorders are the most common disorders diagnosed after psychiatric evaluation. This study is to be the first study examining the psychiatric consultations in the province of Elazı g city. The aim is to compare the results of the present study with the research conducted in other provinces and to lead the psychiatric approaches.

Keywords: Psychiatry, consultation, physical illness, inpatient

Yazışma Adresi: Gülay Taşcı, Elazı ̆̆ Fethi Sekin Şehir Hastanesi, Elazı ̆̆

E-Posta: akcagulay01@gmail.com

Alınma tarihi: 22.08.2020 / Kabul tarihi: 28.09.2020 / Yayımlanma tarihi: 20.09.2021

Bir Şehir Hastanesinde İstenilen Psikiyatri Konsültasyonlarının

Genel Tip Derg 2021;31(3)257-261

Değerlendirilmesi - Taşc1 
İnsan biyopsikososyal bir varlıktır. Bu nedenle hastalık hangi alanda yaşanırsa yaşansın bireyi biyolojik, duygusal, ruhsal ve sosyal olarak olumsuz etkileyebilmektedir. Hastalık, hasta için fiziksel olmasının ötesinde ruhsal, sosyal ve çevresel çok boyutlu bir durumdur ve aynı hastalığa sahip olmasına rağmen, bireylerin şikayetleri farklı olabilmektedir. Hastalığa ve hastaya göre değişmekle beraber fiziksel rahatsızlığa karşı geliştirilen davranışsal ve duygusal tepkileri değerlendirirken hastayı bir bütün olarak ele almak önemlidir (1). Yatarak tedavi gören bireyler gerek hastalığ 1 ile, gerekse hastane ortamıyla ilgili birçok olumsuz duygu, düşünce ve davranışlar gösterebilir. Bu yüzden fiziksel hastalık durumunun ruhsal bozukluk riskini $\operatorname{artırdı} \breve{g} 1$ bilinmektedir $(2,3)$. Kronik fiziksel hastalığı olanlarda ruhsal bozukluk görülme oranı yapılan bir çalışmada \%42 olarak bulunmuştur (4). Yapılan bir çalışmada hastanede yatan hastaların $\% 30$ ve $\% 60$ gibi büyük bir çoğunluğunun psikiyatrik eştanı sergilediği belirtilmektedir $(5,6)$. Psikiyatrik belirtiler; fiziksel bir hastalığın işareti, kronik fiziksel bir hastalığın dolaylı etkisi ya da fiziksel hastalıktan tamamen bağımsız bir şekilde hastanede yatış sürecinde ortaya çıkabilir (7). Ek psikiyatrik rahatsızlığı olan hastalarda hastalığın şiddeti ve ölüm riski $\operatorname{artmıştır~}(7,8)$. Bu durum fark edilmez ve tedavi edilmezse; tedavide olumsuz sonuçlara, yaşam kalitesinde azalmaya, kronikleşmeye ve ikincil komplikasyon riskinde artışa, hastanede uzun süreli ve tekrarlanan yatı̧slara yol açabilir. Sonuç olarak sağlık hizmeti sunucuları için daha yüksek hasta maliyetlerine yol açabilir $(7,8)$. Bu hastaların tanı ve tedavisi psikiyatrik ve psikosomatik konsültasyon-liyezon (KL) hizmetleri ile sağlanabilir (8). Konsültasyon-Liyezon psikiyatrisi (KLP), hem psikiyatrik hem de fiziksel hastalık belirtileri ile başvuran kişilerin bakımına odaklanan psikiyatrik uzmanlık alanıdır. KLP hizmeti esas olarak genel hastane servislerinde, acil servislerinde ve tüm polikliniklerde sunulmaktadır $(8,9)$. KLP hizmetleri danışmanlık, irtibat, özel psikolojik müdahaleler, eğitim ve araştırmanın bir karışımını sağlar, ancak bireysel hizmetler yerel ihtiyaçlara ve koşullara bağlı olarak değişebilir (9). KLP ile ilgili yapılan çalışmalar sağlık hizmeti sunucularının kendilerini değerlendirmelerini, var olan eksiklikleri görmelerini sağlar ve ileriye dönük planlamalarda daha iyi hizmet verebilmeleri için yol gösterici niteliğindedir.

Hastanemiz 2018 yılı ağustos ayında açılmış olup, 1038 yatak kapasitesine ve 227 adet polikliniğe sahip bir şehir hastanesidir. Psikiyatri ekibi olarak 100 yataklı YGAP (yüksek güvenlikli adli psikiyatri hastanesi), iki adet psikiyatri polikliniği, bir adet konsültasyon polikliniği ve bir adet psikiyatri heyet polikliniğinde hizmet vermekteyiz. Yapılan literatür taramasında Elazı̆ ilinin verilerini bir yılı esas alarak ele alan bir KLP çalışmasının bulunmadığı görülmüştür. Bu çalışmada bir yıllık süre içerisinde bir şehir hastanesinden istenen psikiyatri konsültasyonlarını hastaların sosyodemografik özelliklerine, konsültasyon isteyen kliniklere, konsültasyon istem nedenlerine, hastaların esas yatış tanılarına, aldıkları psikiyatrik tanılara ve tedavilere göre incelenmesi amaçlanmıştır.

\section{Materyal ve Metot}

Çalışmamız Fırat Üniversitesi Klinik Araştırmalar Etik Kurulu tarafindan 13.04.2020 tarihinde, 2020/06-28 sayıl1 toplantı kararıla onaylandıktan sonra başlatılmıştır ve Dünya Tıp Birliği Helsinki Bildirgesine uygun olarak yapılmıştır.
01.01.2019-31.12.2019 tarihleri arasında hastanemiz yoğun bakım ünitesi, cerrahi veya dahili servislerinde yatarak tedavi gören 30631 hastadan ve acil servise ayaktan başvuran 353100 kişiden, psikiyatri konsültasyonu istenen 18 yaş ve üstü hastaların verileri hastane kayıt sistemi üzerinden geriye dönük olarak incelenmiştir. Aylara göre konsültasyon istem dağılımı belirlenmiştir. Toplamda 1040 kişiden psikiyatri konsültasyonu istenmiş olup 961 kişiye konsültasyon hizmeti verilebilmiştir. Psikiyatrik görüşmeyi kabul etmeyen 9 hasta, değerlendirme öncesi taburcu edilen yada yerinde bulunamayan 10 hasta, birhaftaiçinde tekrarkonsültasyon istenen 40 hasta, konsültasyon işlemi tamamlanamayan ve verilerinde eksikler olan 20 hasta çalışma dışı bırakılmıştır. Konsültasyon istenen hastaların yaş, cinsiyet gibi demografik verileri, konsültasyon istenen tarih, konsültasyon isteyen bölüm, konsültasyon istem nedeni, konsültasyonun ayaktan mı yatan hastaya $\mathrm{m} 1$ ait olduğu, hastaların hastanede esas yatış tanıları ve ek tıbbi hastalıkları, DSM-5 tanı kriterlerine göre yarı yapılandırılmış klinik görüşme ile psikiyatri uzmanlarınca konulan psikiyatrik tanıları ve önerilen psikiyatrik tedavileri ile ilgili tüm verileri tarafımızca hazırlanmış yarı yapılandırılmış veri formlarına kaydedilmiştir.

Çalışmamızda özkıyım girişiminde bulunan hastalara ait veriler ayrıca değerlendirilmiştir. Özkıyım girişim yöntemleri, hastaların DSM-5 tanı kriterlerine göre aldıkları psikiyatrik tanılar ve önerilen tedaviler değerlendirilmiştir.

\section{İstatistiksel Analiz}

İstatistiksel analizlerde SPSS 22.0 programı (Statistical Package for the Social Sciences Inc.) kullanıldı. Tanımlayıcı istatistikler ve sürekli değişkenler ortalama \pm standart sapma, kategorik değişkenler ise frekans ve yüzde olarak verildi.

\section{Bulgular}

2019 y1lı boyunca 961 hastaya psikiyatri konsültasyon hizmeti verilmiştir. Hastanemizde bir yıllık süre içerisinde acil servis, pediatri ve psikiyatri servisleri dışında 30631 hasta yatarak tedavi görmüş olup, bu hastalardan konsültasyon istenme oran1 $\% 3$ 'tür. Konsültasyon istenen hastaların 511'i (\%53.2) kadın, 450'si (\% 46.8) erkeklerden oluşuyordu. Hastalardan kadınların yaş ortalaması $53.65 \pm 21.5$ yıl, erkeklerin ise $57.59 \pm 21.38$ yıl idi. Hastalar $18-83$ yaş aralığında olup, total yaş ortalaması ise $55.50 \pm 21.55 \mathrm{y} 1 \mathrm{idi}$.

Olguların konsültasyon istem nedenlerine bakıldığında 652 kişiye (\%68) bir sebep belirtilmeden psikiyatrik değerlendirme istemi ile, 71 (\%7) kayg1, 46 (\%5) uykusuzluk, 41(\%4) operasyon öncesi psikiyatrik değerlendirme, 45 (\%5) özkıyım girişimi, 43 (\%4) psikiyatrik ilaç tedavisinin düzenlenmesi, 27 (\%3) ajitasyon, 17 (\%2) depresif belirtiler, 29 (\%3) kişiye diğer sebepler nedeniyle istem yapılmıştır.

Bunlardan 204 (\%21.2) kişi YBÜ, 280 (\%29.1) kişi cerrahi servisler, 454 (\% 47.3) kişi ise dahili servislerde yatarak tedavi gören, 23 (\%2.4) kişi acil servise başvuran hastalardan oluşuyordu. Konsültasyon isteyen bölümlerin istem sayıları ve oranları ayrıntılı olarak tabloda sunulmuştur (Tablo 1).

Bir Şehir Hastanesinde İstenilen Psikiyatri Konsültasyonlarının Değerlendirilmesi - Taşc1 
Tablo 1. Konsültasyon İsteyen Klinikler

\begin{tabular}{|c|c|c|}
\hline İsteyen Klinikler & Sayı (n) & $\%$ \\
\hline \multicolumn{3}{|l|}{ Dahili Servisler } \\
\hline Göğüs Hastalıkları servisi & 128 & 13.3 \\
\hline Dahiliye servisi & 105 & 10.9 \\
\hline FTR servisi & 53 & 5.5 \\
\hline Kardiyoloji servisi & 50 & 5.2 \\
\hline Nöroloji servisi & 41 & 4.3 \\
\hline Enfeksiyon servisi & 25 & 2.6 \\
\hline Palyatif bakım servisi & 15 & 1.6 \\
\hline Radyasyon onkolojisi servisi & 9 & 0.9 \\
\hline Diğer dahili (Göz,KBB,Üroloji) servisler & 28 & 2.9 \\
\hline \multicolumn{3}{|l|}{ Cerrahi servisler } \\
\hline Genel cerrahi servisi & 200 & 20.8 \\
\hline Ortopedi servisi & 39 & 4.1 \\
\hline Kalp damar cerrahi servisi & 10 & 1.0 \\
\hline KBB servisi & 10 & 1.0 \\
\hline Diğer cerrahi servisler & 21 & 2.2 \\
\hline \multicolumn{3}{|l|}{ Yoğun Bakım Üniteleri } \\
\hline Anestezi YBÜ & 82 & 8.5 \\
\hline Dahiliye YBÜ & 62 & 6.5 \\
\hline Göğüs YBÜ & 20 & 2.1 \\
\hline Genel cerrahi YBÜ & 17 & 1.8 \\
\hline Beyin cerrahi YBÜ & 12 & 1.2 \\
\hline Diğer YBÜ'ler & 11 & 1.1 \\
\hline Acil servis & 23 & 2.3 \\
\hline
\end{tabular}

Konsültasyon istenen hastaların hastaneye yatış tanıları endokrinolojik sebepler ( $\mathrm{n}=228, \% 23.7)$, göğüs hastalıkları ile ilgili nedenler $(\mathrm{n}=165$, \%17.2), özkıyım girişimi ( $\mathrm{n}=123, \% 12.8)$, nörolojik nedenler $(\mathrm{n}=105$, $\% 10.9)$, kardiyolojik nedenler $(\mathrm{n}=75, \% 7.8)$ en s1k nedenlerdir (Tablo 2).

Tablo 2. Hastaların Ana Yatış Tanıları

\begin{tabular}{lll}
\hline Yatıs Tanıları & Sayı (n) & $\%$ \\
\hline Endokrinolojik hastalıklar & 228 & 23.72 \\
Göğüs hastalıkları & 165 & 17.16 \\
İntihar girişimi & 123 & 12.79 \\
Nörolojik hastalıklar & 105 & 10.92 \\
Kardiyolojik hastalıklar & 75 & 7.80 \\
Kanserler & 55 & 5.72 \\
Acil cerrahi nedenler & 37 & 3.85 \\
Kemik fraktürü & 33 & 3.43 \\
Kafa travması & 32 & 3.32 \\
Acil psikiyatrik nedenler & 28 & 2.91 \\
Gastrointestinal sistem hastalıkları & 26 & 2.70 \\
Nefrolojik hastalıklar & 16 & 1.66 \\
Enfeksiyon hastalıkları & 14 & 1.45 \\
Diğer nedenler & 24 & 2.49
\end{tabular}

Konsültasyon isteme sıklığı aylara göre bakıldığında en s1k mart $(\mathrm{n}=115, \% 12)$, aralık $(\mathrm{n}=93, \% 9.7)$, mayıs $(\mathrm{n}=92, \%$ 9.6) aylarıdır. Mevsimsel sıralama ise ilkbahar ( $\mathrm{n}=282, \% 29.4)$, kış ( $\mathrm{n}=264, \% 27.5)$, sonbahar ( $\mathrm{n}=219, \% 22.8)$, yaz $(\mathrm{n}=196, \% 20.4)$ şeklindedir (Tablo 3).

Bir Şehir Hastanesinde İstenilen Psikiyatri Konsültasyonlarının

Değerlendirilmesi - Taşc1
Tablo 3. Konsültasyon İstenilen Aylar

\begin{tabular}{lll}
\hline Konsültasyon istenen ay & Sayı (n) & \% \\
\hline Ocak & 84 & 8.7 \\
Şubat & 87 & 9.0 \\
Mart & 115 & 12.0 \\
Nisan & 75 & 7.8 \\
Mayıs & 92 & 9.6 \\
Haziran & 59 & 6.1 \\
Temmuz & 72 & 7.5 \\
Ağustos & 65 & 6.8 \\
Eylül & 77 & 8.0 \\
Ekim & 66 & 6.9 \\
Kasım & 76 & 7.9 \\
Aralık & 93 & 9.7
\end{tabular}

Hastaların DSM-5 tanı ölçütlerine dayanan klinik görüşme sonrası aldıkları tanılar ise; anksiyete bozuklukları (genel tıbbi duruma bağlı anksiyete bozukluğu, yaygın anksiyete bozukluğu, panik bozukluk, tanımlanmamış anksiyete bozukluğu) 409 (\%42.6) kişi, depresif bozukluk 131 (\%13.6) kişi, uyum bozukluğu 70 (\%7.3) kişi, deliryum 45 (\%4.7) kişi, uyku bozukluğu 43 (\%4.5) kişi, bipolar bozukluk 21 (\%2.2) kişi, şizofreni 11 (\%1.1) kişi, kişilik bozukluğu 10 (\%1) kişi ile en sık konulan tanılar olmuştur. 190 (\%19.8) kişide ise psikiyatrik tanı ölçütlerini karşılayacak bir hastalık saptanmamıştır ve bir tedavi önerilmemiştir. (Tablo 4). Hastalardan 658 (\%68.5) antidepresan (essitalopram, sertralin, venlafaksin ve duloksetin) ilaç tedavisi, 45 (\%4.7) antipsikotik (haloperidol damla, ketiapin ve olanzapin) ilaç tedavisi, $19(\% 2)$ kişiye antidepresan ve antipsikotik kombine tedavi, 12 (\%1.2) kişiye duygudurum düzenleyici, 180 (\%18.8) ilaçsız takip, 47 (\%4.8) kişiye psikiyatri servisinde yatarak tedavi görmesi önerilmiştir.

Tablo 4. Hastaların Aldıkları Psikiyatrik Tanılar

\begin{tabular}{lll}
\hline Psikiyatrik tanı & Sayı (n) & \% \\
\hline Anksiyete bozuklukları & 409 & 42.6 \\
Depresif bozukluk & 131 & 13.6 \\
Uyum bozukluğu & 70 & 7.3 \\
Deliryum & 45 & 4.7 \\
Uyku bozukluğu & 43 & 4.5 \\
Bipolar bozukluk & 21 & 2.2 \\
Şizofreni & 11 & 1.1 \\
Kişilik bozukluğu & 10 & 1.0 \\
Konversiyon bozukluğu & 9 & 0.9 \\
Akut psikoz & 9 & 0.9 \\
Somatizasyon bozukluğu & 6 & 0.6 \\
Obsesif kompulsif bozukluk & 5 & 0.5 \\
Zeka geriliği & 2 & 0.2 \\
Psikiyatrik tanı almamış & 190 & 19.9
\end{tabular}

Özkıyım girişimi nedeniyle acil servis, anestezi ve dahiliye yoğun bakım ünitelerinde değerlendirilen 123 hastadan 71(\%57.73) kişi kadın, $52(\% 42.27)$ kişi erkekti. Hastaların yaş ortalaması $30.64 \pm 5.64$ yıl idi. 108 (\%87.8) hastanın özkıyım girişimi ilaçla, 6 (\% 4.87) hastanın boyun bölgesine kesici aletle, 5 (\% 4.06) hastanın as1 ile, 4 (\%3.25) hastanın ise yüksekten atlayarak olmuştur. 3 (\% 2.41) hastanın özkıyım girişiminde bulunduğunda gebeliği mevcuttu. Hastalar aldıkları tanı açısından değerlendirildiğinde; depresif bozukluk, anksiyete bozukluğu, uyum bozukluğu, kişilik 
bozukluğu en sık konulan tanılar olmuştur. 12 kişide ise ruh sağlığ ve hastalıkları açısından tanı ölçütlerini karşılayacak bir hastalık saptanmamıştır ve tedavi önerilmemiştir. Hastaların aldıkları tanılar tabloda gösterilmiştir (Tablo 5).

Tablo 5. Özkıyım Girişimi Olan Hastaların Aldıkları Psikiyatrik Tanilar

\begin{tabular}{lll}
\hline Özkıyım girişimi ile alınan tanı & Sayı (n) & \% \\
\hline Depresif bozukluk & 44 & 35.77 \\
Anksiyete bozukluğu & 27 & 21.95 \\
Uyum bozukluğu & 21 & 17.07 \\
Kişilik bozukluğu & 8 & 6.50 \\
Akut psikoz & 5 & 4.06 \\
Bipolar bozukluk & 4 & 3.25 \\
Obsesif kompulsif bozukluk & 2 & 1.62 \\
Psikiyatrik tanı almamış & 12 & 9.75
\end{tabular}

\section{Tartışma}

Çalışmamızda bir yıllık süre içerisinde psikiyatri bölümünden istenen konsültasyonlar geriye dönük olarak incelenmiștir. Kadın hastalardan erkeklere oranla daha çok konsültasyon istendiği, konsültasyonların daha çok bir neden belirtilmeksizin istendiği, en s1k konsültasyon isteyen bölümlerin dahili bölümler olduğu, konsültasyon istenen hastalarda en s1k endokrinolojik hastalıklar olduğu, hastalara en s1k anksiyete bozukluğu tanısı konulduğu ve antidepresan ilaç tedavisi önerildiği görülmüştür.

Çalışmamızda konsültasyon istem oranının \%3 olduğu, bu oranın bir çalışmada 2.8 (17), başka bir çalışmada 1.37 (18) olarak bulunduğu görülmüştür. Psikiyatri konsültasyon istem oranının düşük olması fiziksel hastalıklara eşlik eden psikiyatrik rahatsızlıkların yeterince farkedilemediğini düşündürmüştür.

Çalışmamızın sosyodemografik verilerine göre konsültasyon istenen hastaların \%53.2'si kadın, \%46.8'i erkeklerden oluşuyordu. Literatürde yapılan çalışmaların büyük çoğunluğunda kadınların oranının daha yüksek olduğu görülmüştür $(10,11,12)$. Kadınlarda ruhsal bozuklukların daha sık ve yaygın görülmesi biyolojik, ruhsal, toplumsal, kültürel ve sosyolojik nedenlere bağlanmıştır (13). Ayrıca bu sonuç kadınların erkeklere göre kendilerini sözel olarak daha iyi ifade edebildiği ve ruhsal sorunları tanıma ve ifadede daha iyi oldukları ile ilgili olduğu yapılan bir çalışmada bildirilmiştir (12). Yaş açısından bakıldığında ise hastaların yaş ortalamasının yüksek olduğu görüldü. Fiziksel hastalıkların artış gösterdiği yaşlarda konsültasyon sayısının yoğun olması beklenen bir sonuçtur. Yapılan birçok çalışmada psikiyatri konsültasyonu istenen hastaların 45-55 yaşları arasında olduğu bildirilmiştir $(10,12,14,15)$.

Çalışmamızda en sık psikiyatri konsültasyon istem nedeni, \%68 oranla bir sebep belirtilmeksizin psikiyatrik değerlendirmedir. Literatüre bakıldığında bu konuda çeşitli sonuçların olduğu görülmektedir. Yapılan iki çalışma bizim sonucumuzla uyumlu iken $(12,27)$, başka çalışmalarda en sık istem nedeni olarak ajitasyon $(15,18)$ ve depresif şikayetler $(11,19)$ olduğu belirtilmiştir.

Başta duygudurum bozuklukları olmak üzere psikiyatrik rahatsızlıkların mevsimsel özellik gösterdiği ve sonbahar, kış aylarında yaklaşık olarak Kasım'dan Mart'a kadar güneş 1şı̆̆ındaki azalmaya bağlı olarak ortaya çıktığı bilinmektedir (16). Bizim çalışmamızda konsültasyon istemlerinin en s1k mart ayında en az ise haziran ayında; mevsimsel olarak ise en s1k ilkbahar, en az yaz aylarında olduğu görülmektedir. Aylara yada mevsimlere göre konsültasyon dağılımını inceleyen çok az sayıda çalışma vardır (14). Yapılan bir çalışmada tüm hastalar için ve bipolar bozukluk hastaları için konsültasyon istenme oranının mevsimlere göre değişkenlik göstermediği bildirilmiştir (14). Bizim çalışmamızda sonbahar ve kış aylarında konsültasyon isteminin az olmasının sebebi, acil müdahale ve yatış gereken psikiyatri hastalarının kapalı servisi olan Elazı̆̆ Ruh Sağlığı ve Hastalıkları (ERSH) hastanesinde tedavi görmelerine bağlanmıştır.

Çalışmamızda dahili bölümlerden istenen konsültasyon oranının (\%47.3) cerrahi bölümlere (\%29.1) göre literatürle uyumlu olarak çok daha yüksek olduğu görülmüştür $(10,15)$. En sık konsültasyon istenen bölümler ise göğüs hastalıkları, dahiliye, genel cerrahi servisleri ve anestezi yoğun bakım ünitesi olarak sıralanmıştır. Yapılan birçok çalışmada dahiliye ve göğüs hastalıkları en çok konsültasyon istenen bölümler olmuştur $(17,18)$. Bizim çalışmamızda ise diğer çalışmalardan farklı olarak göğüs hastalıkları ilk sırada, dahiliye ise ikinci sırada yer almıştır. Bu durum göğüs hastalıkları servis yatak sayısının dahiliye servisinden daha yüksek olmasına bağlanmıştır. Acil servise ayaktan başvuran hastalardan istenen konsültasyon sayıs1 23 ve oranı \% 2.4'dür. $\mathrm{Bu}$ oranın düşük olması ERSH hastanesinde psikiyatri acil servisinin olmasına ve acil psikiyatrik hastaların buraya daha fazla başvurmalarına bağlanmıştır. Ayrıca hastanemiz acil servisinden istenen konsültasyonlar daha çok cerrahi müdahale gerektiren kendine zarar verici davranışlar ve özkıyım girişimleri nedeniyle olmaktadır.

Hastaların hastanede esas yatış tanıları açısından değerlendirildiğinde literatürde çok farklı verilerin olduğu görülmüștür. Canan ve ark. (17) travma, Eğilmez ve ark. (14) özkıyım girişimi, Kahyacı-Kılıç ve ark.(19) ise kanseri yaptıkları çalışmalarda ilk sırada yer alan tanılar olarak bildirmişlerdir. Bizim çalışmamızda ilk sırada endokrinolojik hastalıklar, ikinci sırada göğüs hastalıkları yer almaktaydı. Sonuçlar arasındaki bu farklılık her hastanenin hizmet verme şartlarının ve imkanlarının farklı olmasına bağlanmıştır. Ayrıca yapılan çalışmaların çoğunda hastaların ana yatış tanıları incelenmemiştir. Bizim çalışmamız bu açıdan önemli bulgular sunmaktadır.

Psikiyatrik muayene sonucunda konulan psikiyatrik tanılar ise anksiyete bozuklukları, depresif bozukluk, uyum bozukluğu, deliryum, uyku bozukluğu, bipolar bozukluk şeklinde sıralanmıştır. Yapılan çalışmalarda genel olarak ilk iki sırada depresif bozukluklar ve anksiyete bozuklukları yer almaktadır $(12,14,17)$. Bu açıdan bizim çalışmamız da literatürle uyumludur.

Değerlendirilen 961 hastadan 190 kişiye psikiyatrik bir tanı konulmamıştır. Psikiyatrik tanı konulma oranı bizim çalışmamızda \%80.2'dir. Yapılan çalışmalarda da bu oranların \%75.8-95.8 olarak tespit edilmiştir $(12,17)$. Bu oranın düşük olması psikiyatrik semptomların psikiyatrist dışı hekimler tarafından yeterince tanınmadığı ya da hastaların somatik semptomlarının fiziksel bir hastalık saptanamadığında psikiyatrik yakınmalar olarak değerlendirildiği şeklinde yorumlanmıştır.

Çalı̧̧mamızda \%76.4 oranında hastalarımıza ilaç tedavisi önerildiği, en sık önerilen ilaçların ise antidepresanlar (essitalopram, sertralin, venlafaksin ve duloksetin) ve antipsikotiklerin (haloperidol damla, ketiapin ve olanzapin) olduğu görülmüştür. Çalışmamız bu yönüyle 
literatürle uyumludur $(18,27)$.

Özkıyım girişimleri psikiyatrik aciller arasında en sık rastladığımız durumlardır. Çalışmamızda özkıyım girişiminde bulunan 123 hasta, tüm konsültasyonların \% 12.8'ini oluşturuyordu. Bu oran çalışmalarda farklılık göstermektedir $(10,19)$. Bu farklılık her hastanenin verdiği sağlık hizmetinin farklı olmasına, bölgede birden fazla psikiyatri ya da yoğun bakım servisi olmasına bağlanmıştır.

Çalışmamızda literatürle uyumlu olarak özkıyım girişiminde bulunan kadınların sayısının erkeklerden fazla olduğu görülmüştür $(20,21)$. Erkeklerde tamamlanmış intihar oranları yüksek iken, kadınlarda intihar girişimi daha fazladır (22). Hastaların yaş ortalaması ise $30.64 \pm 5.64$ yıldır. $\mathrm{Bu}$ ortalama psikiyatri konsültasyonu istenen diğer hastaların yaş ortalamasından düşüktür. Ülkemizde yapılan bir çalışmada özkıyım girişimlerinin 15-24 yaş aralığında artış gösterdiği (23), başka bir çalışmada ise; acile başvuran özkıyım girişimi vakalarının 15-34 yaş aralığında $(\%$ 81,3) yoğunlaştığı belirtilmiştir (24).

Özkıyım girişiminde bulunan hastalara en sık konulan tanı depresif bozukluk olmuştur. Literatürde yapılan birçok çalışmada depresif bozukluk en sık konulan psikiyatrik tanıdır $(25,26)$. Özkıyım girişiminde kullanılan en sık yöntem ise \% 87.8 oranla ilaçla ve toksik madde ile olmuştur. Yapılan birçok çalışmada ilk sırada ve \% 90 oranlarında ilaç ve toksik maddenin olduğu görülmüştür $(10,26)$. $\mathrm{Bu}$ yöntemin en sık kullanılması, ilacın ve maddenin kolay ulaşı1labilir olmasına bağlanmıştır.

$\mathrm{Bu}$ çalışmanın kısıtlılıklarından biri tanısal değerlendirmenin yapılandırılmış bir yöntemle yapılmamış olmasıdır. Ayrıca hastalara ait verilerin bilgisayar sistemi üzerinden geriye dönük olarak incelenmesidir. Konsültasyon sonrası psikiyatrik takip önerilen hastaların kontrol kayıtlarının incelenmemesi de bir diğer kısıtlılıktır Ülkemizde hastaneye başvuran hastaların psikiyatrik morbiditelerinin belirlenmesi için daha geniş çaplı ve yapılandırılmış görüşme tekniklerinin kullanıldığı araştırmalara ihtiyaç vardır.

Sonuç olarak Elazı̆̆ ili psikiyatri konsültasyonlarını incelediğimiz bu çalışmada veriler diğer illerdeki verilerle benzerlik göstermekle birlikte, çalışmamızda ayaktan başvuran ve yatan hastaların dahil edilmesi, mevsimsel özellikle ilgili verilerin incelenmesi, özkıyım girişimlerinin ayrıca değerlendirilmesi çalışmamızı diğer çalışmalardan ayıran özelliklerdir. Bu çalışma Elazı̆̆ iline ait psikiyatri konsültasyonlarını inceleyen ilk çalışmadır. Diğer servislerde yatarak tedavi alan ve ayaktan acil servise başvuran hastalardan istenen psikiyatri konsültasyonları ile hastalara tanı konulup tedavi almaları için bir firsat olduğu düşünülmektedir. Bu çalışmadan elde edilen veriler psikiyatrik yardıma yönelik hizmetlerin planlanmasında ve iyileştirilmesinde yol gösterici olabilir.

\section{Kaynaklar}

1.Özkan S. Genel tıpta depresyon . Hipokrat Dergisi 2001; 10: 79-83.

2.Abalı O, Tüzün Ü, Gürkan K. Çocuk psikiyatrisi konsültasyonlarının değerlendirilmesi. Genel Tıp Dergisi 2006; 16(3): 121-24.

3.Grau MA, Suner R, Abuli P. Anxiety and depression levels in medical inpatients and their relation to the severity of illness. J Behaviour Medicine 2003; 26: 119-32.

4.Hochlehnert A, Niehoff D, Herzog W ve ark. Elevated costs of treatment in medical inpatients with psychiatric comorbidity are not reflected in the German DRG-system Psychother Psychosom Med Psychol 2007; 57: 70-5
5.Hall RCW, Rundel JR, Popkin MK. Cost effectiveness of the consultation- liasion service. Wise MG, Rundel RJ, editors. Textbook of consultation -Liasion Psychiatry. Washington, DC: American Psychiatric Publishing 2002; 25-32.

6.Rothenhausler HB. Mentaldisorders in general hospital patients. Psychiatria danubina. 2006; 18: 183-92.

7.Fink P, Hansen MS, Sondergaard L. Somatoform disordersamong first-time referrals to a neurology service. Psychosomatics 2005; 46: 540-8.

8.Stein B, Müller MM, Meyer LK, Söllner W, CL Guidelines Working Group. Psychiatric and Psychosomatic Consultation-Liaison Services in General Hospitals: A Systematic Review and Meta-Analysis of Effects on Symptoms of Depression and Anxiety. Psychotherapy and Psychosomatics 2020; 89: 6-16.

9.Hopkins J, Cullum S, Sundram F. The state of play-the first national survey of consultation-liaison psychiatry services in New Zealand. Australas Psychiatry 2020;1-6.

10.Özsoy, F. Ruh sağlığı ve Hastalıkları Bölümünden İstenen Konsültasyonların geriye Dönük İncelenmesi. Gaziosmanpaşa Üniversitesi Tıp Fakültesi Dergisi 2018;10(2): 46-

11.Uyar B, Gürgen F. Bir Üniversite Hastanesinde Psikiyatri Konsültasyonlarının Değerlendirilmesi. Klinik Psikiyatri Dergisi 2015; 18(1):24-8.

12.Kuloğlu M, Çayköylü A, Akyol Soydaş E, Ibiloğlu A, Yılmaz E. Bir eğitim hastanesinde istenen psikiyatri konsültasyonlarının değerlendirilmesi. Kriz dergisi 2008;16(1):19-24

13.Önen FR, Kaptanoğlu C, Seber G. Kadınlarda Depresyonun Yaygınlığı Ve Risk Faktörlerle İlişkisi. Kriz Dergisi 1995; 3(1-2): 88-103.

14.Eğilmez OB, Örüm MH, Kara MZ, Örüm G. Bir Eğitim Ve Araștırma Hastanesinde Ayaktan ve Yatan Hastalar İçin İstenen Psikiyatri Konsültasyonlarının Değerlendirilmesi: 2018 Yılı Verileri. Ankara Eğitim Ve Araştırma Hastanesi Tıp Dergisi 2019; 52(3):257-

15.Ertek İE, Öztürk HM. Bir eğitim-araştırma hastanesinde istenen psikiyatr konsültasyonlarının değerlendirilmesi ve psikiyatrik hastalıkların doğru tanınma oranları. Klinik Psikiyatri Dergisi 2019; 22 (3):338-46.

16.Wirz-Justice A. Seasonality in affective disorders. General and comparative endocrinology 2018;258:244-9.

17.Canan F, Kocer E, İcmeli C, ve ark. Bir universite hastanesinde yatan hastalar icin istenen psikiyatri konsultasyonlarının değerlendirilmesi. Duzce Tıp Fakultesi Dergisi $2008 ; 1: 22-7$.

18.Köroğlu A, Helvacı-Celik F, Aslan M, ve ark. Bir eğitim hastanesinde psikiyatr konsültasyon hizmetlerinin değerlendirilmesi. Klinik Psikiyatri 2011;14:44-50.

19.Kahyac1-Kılıc E, Kose-Cinar R, Sonmez MB, Gorgulu Y. Bir üniversite hastanesinde yatan hastalardan istenen psikiyatrik konsültasyonların değerlendirilmesi. Klinik Psikiyatri 2016;19:194-201.

20.Dilbaz N, Şengül C, Okay T. Genel Bir Hastanede İntihar Girşimlerinin Değerlendirilmesi. Kriz Dergisi 2005;13:1-10.

21.Yalvaç D. İntihar Girişiminde Bulunan Bireylerde Psikiyatrik Morbidite, Kișilik Bozukluğu ve Bazı Sosyodemografik ve Klinik Etmenlerle İlișkisi. Uzmanlık Tezi. Malatya, İnönü Üniversitesi, Tıp Fakultesi. 2006.

22.Ișı1k E, Ișık U, Taner Y. Cocuk, Ergen, Erișkin ve Yaşlılarda Depresif ve Bipolar Bozukluklar; Ziraat Gurup Matbaacılık, 2013, Ankara.

23.Al B, Orak M, Üstündağ M, Sögüt Ö. Characteristics of suicides cases in Batman, South East of Turkey. Turkiye Klinikleri Journal of Medical Sciences 2010; 30: 65-72.

24.Dolaşır S. Yılında Ankara Üniversitesi Tıp Fakültesi Hastanesi Acil Servis Kriz Odasına Başvuran İntihar Girișimi Vakalarının Bir Y1l Sonraki Ruhsal Durumları Ve İntihar Davranıșını Yineleme Riskleri. Ankara, Yayınlanmamıs Yüksek Lisans Tezi. 2005 .

25.Deveci A, Aydemir Ö, Mızrak S. İntihar girisiminde bulunanlarda sosyodemografik özellikler, stres etmenleri ve ruhsal bozukluklar. Kriz Dergisi 2005;13:1-9.

26.Mete B, Söyiler V, Pehlivan E. Psikiyatrik bozukluklar ile özkıyım arasındaki iliskinin incelenmesi: 2013-2018 yılları için kayıtlara dayalı geriye dönük bir araştırma. Klinik Psikiyatri Dergisi 2020; 23:92-100

27.Göktaş K, Yılmaz E, Kaya N ve ark. Bir Eğitim Hastanesinde İstenen Psikiyatr Konsültasyonlarının Değerlendirilmesi. Anadolu Psikiyatri Dergisi 2006;7:27-32. 